\section{Natural titanium dioxide nanotubes}

Aleksei V. PONARYADOV - Institute of Geology, Komi Science Center, Ural Branch of the Russian Academy of Sciences, Russian Federation • avponaryadov@geo.komisc.ru

OLGA B. KOTOVA - Institute of Geology, Komi Science Center,

Ural Branch of the Russian Academy of Sciences, Russian Federation • kotova@geo.komisc.ru

Монамmed TIHTIH - Institute of Ceramics and Polymer Engineering, University of Miskolc, Hungary - medtihtih@gmail.com

SHIYoNG SUN - Institute of Non-metallic Minerals, Department of Geological Engineering, School of Environment and Resource, Southwest University of Science and Technology, People's Republic of China • shiysun@163.com

Érkezett: 2020. 06. 30. - Received: 30. 06. 2020. - https://doi.org/10.14382/epitoanyag-jsbcm.2020.25

\section{Abstract}

One-dimensional nanosized structures based on titanium dioxide are a desirable product because of their physical and chemical properties. The article considers production of titanium dioxide nanotubes based on ilmenite-leucoxene ores and products of their processing. Titanium dioxide nanotubes were synthesized by hydrothermal treatment in an alkaline solution from a gravity concentrate of ilmenite-leucoxene ore from the Pizhemskoe deposit. In the samples we found phases of quartz and sodium titanate $\mathrm{Na}_{x} \mathrm{H}_{2-x} \mathrm{Ti}_{3} \mathrm{O}_{7}$. Nanostructuring results in increasing specific surface area and decreasing band gap. We evaluated effectiveness of synthesized samples in the photocatalytic decomposition of organic pollutants in aqueous solutions. We showed that they were not inferior to commercial analogues by their effectiveness.

Keywords: functional materials, titanium dioxide, nanotubes, ilmenite-leucoxene ore, photocatalysis

Kulcsszavak: funkcionális anyagok, titán-dioxid, nanocsövek, ilmenit-leucoxén érc, fotokatalízis
Aleksei V. PONARYADOV is a Researcher of Laboratory of Technology of Mineral Raw, Institute of Geology, Komi Science Center, Ural Branch of the Russian Academy of Sciences. Author and co-author of more than 30 scientific articles. Russian Mineralogical Society.

Olga B. KOTOVA

is Dr.Sc., Head of Laboratory of Technology of Mineral Raw, Institute of Geology, Komi Science Center, Ural Branch of the Russian Academy of Sciences. Author and co-author of 4 patents and more than 200 scientific articles. President of ICAM-2019. The member of Science Council of Russian Mineralogical Society.

Mohammed TIHTIH Is a lecturer in the Sidi Mohamed Ben abdellah University, Morocco, he graduated from Faculty of sciences Dhar El Mahraz, Fez, Morocco, Department of Physics, for the time being, he is a PhD student in the University of Miskolc, Institute of Ceramics and Polymer Engineering, under supervision of Prof. L. A. Gömze

Shiyong SUN

is a Professor and Head of School of Environment and Resource at the Southwest University of Science and Technology. Author and co-author of more than 100 scientific articles.

\section{Introduction}

Composite and other advanced materials can obtain properties of the initial raw [1-3]. Titanium dioxide-based materials attract attention of scientists and engineers due to a set of physical and chemical characteristics (for example, high Ti-O bond strength, low redox potentials).

Due to optical properties, it was most widely used in the paint and varnish industry and in the production of pigments. Also, the objects of close attention of researchers are sensor, adsorption, optical, electrical and catalytic properties of $\mathrm{TiO}_{2}$. The photocatalytic properties of $\mathrm{TiO}_{2}$ are also a subject of increased interest, which allows increasing efficiency of technological processes for the photocatalytic purification of water and air from toxic organic impurities. Chemical and biological inertness allows creating anticorrosion coatings, matrices for the disposal of radioactive waste, and implants [4-6].

The trend of recent decades has been a directed change of the physical and chemical properties of various materials at the nanoscale [7-11]. Particular attention is drawn to the production of nanostructured $\mathrm{TiO}_{2}$ particles [12-18], which is associated with the physical and chemical properties of nanoparticles other than macroparticles, such as gravity forces, chemical, electromagnetic, rheological, or optical. The most of published works on the synthesis of nanostructured $\mathrm{TiO}_{2}$ particles are devoted to synthetic raw materials.

Practically no attention is paid to producing titanium nanodioxide from natural raw - in particular, from a gravity concentrate of titanium ores. When developing new or adapting existing methods, a complex nature of natural raw should be considered. Thus, in ilmenite-leucoxene ores (Pizhemskoe titanium deposit), the main source of valuable components is ilmenite and its alteration products (leucoxene), which are represented by polymineral microaggregates with complex morphostructural features, in which quartz grains occupy up to $30 \%$ (on average). Therefore, during producing nanostructured titanium dioxide directly from the gravity concentrate of ilmenite-leucoxene ore, we should consider possibility of their removal or dissolution.

The aim of this work is to study synthesis of nanostructures based on natural titanium raw - leucoxene ore, and their physical-chemical properties.

\section{Materials and experiments}

\subsection{Materials}

We used samples of gravity concentrate of ilmenite-leucoxene ore from the Pizhemskoe deposit, Russia (hereinafter - LC). At hydrothermal synthesis, $\mathrm{NaOH}$ (purity $\geq 98 \%$ ), $\mathrm{HCl}$ ( $\geq 85 \%$, NevaReaktiv) were used without additional purification. For the preparation of working solutions, deionized water was used.

\subsection{Synthesis of nanostructures}

In a typical preparation $0.8 \mathrm{~g}$ of starting ore (reduced size) was placed in $100 \mathrm{ml}$ autoclave, where $80 \mathrm{ml}$ of $10 \mathrm{M} \mathrm{NaOH}$ solution were added. The autoclave was kept at $110^{\circ} \mathrm{C}$ during 24 $\mathrm{h}$ (temperature sensor was mounted on the stove, not inside the autoclave). After the hydrothermal reaction the autoclave was cooled to room temperature, and the resulting flaky precipitate was washed successively by distilled water and solution of hydrochloric acid $(0.1 \mathrm{M})$ until neutral $\mathrm{pH}(6.5-7)$. The washed samples were dried in the oven at $90^{\circ} \mathrm{C}$ for 12 hours.

\subsection{Samples characterization}

The morphology, phase and chemical composition of the starting ore and as-synthesized samples were studied using a complex of modern analytical equipment in Institute of Geology Komi SC 
UB RAS and Southwest University of Science and Technology. Nanotubes were visualized by scanning electron microscopy (TESCAN Vega 3; SIRMA 300). The crystalline structures of the initial ore and synthesized samples were analyzed by diffractometer (Shimadzu XRD-6000), the material composition was studied by X-ray fluorescence (XRF Shimadzu-1800).

The photocatalytic activity of the samples was studied using a test reaction of decomposition of trichlorophenol in Hereaus circular reactor of a volume of $350 \mathrm{~cm}^{3}$. Vertically to the reactor axis the TQ150 Z2 mercury lamp (150 W, 352-540 $\mathrm{nm}$ ) was located. The control solutions were analyzed by liquid chromatography (Hypersil C18 reverse phase HPLC column). The solvent was a solution of acetonnitrile in water in a ratio of 3:2. The solvent flow was $0.5 \mathrm{ml} / \mathrm{min}$.

\section{Results and discussion}

\subsection{Mineralogical analysis}

The titanium minerals in LC sample are represented by ilmenite, rutile, anatase. Leucoxene, an aggregate of rutile and quartz, is represented by grains of yellow and slightly pinkish color and elongated along one of the axes [19].

The phase analysis showed that LC is basically a mixture of two phases: rutile and quartz (Fig. 1, A). The peaks are clear, indicating a high degree of perfection of rutile. Weak reflexes of ilmenite and anatase are present.

LC is represented by rounded isometric and oval flattened aggregates of needle microcrystals of rutile and quartz with relics of pseudorutile (Fig. 1, B-C). Rutile microcrystals form a sagenite lattice of rutile twins, fused at an angle of $60^{\circ}$. There are also areas of development of anatase crystallites, which are a homogeneous mass. The quartz grains have clear crystallographic forms, the surface is porous.

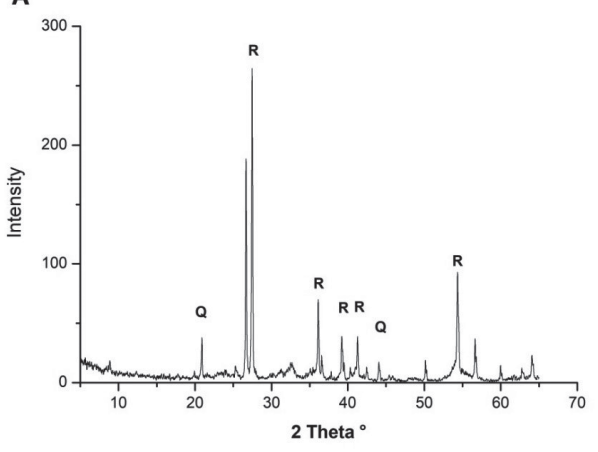

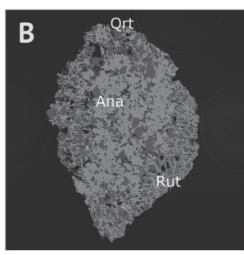

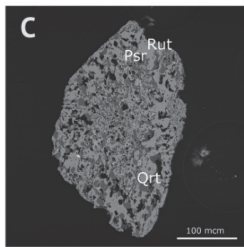

1. ábra A - LC diffrakciós minta ( $Q$ - kvarc, $R$ - rutil); $B, C$ - leucoxén szemcsék anatáz zárványokkal: Rut - rutile, Ana - anatase, Psr - pseudorutile, Qrtquartz. Az ásványi fázisokat EBSD határozta meg.

Fig. 1 A-LC diffraction pattern ( $Q$ - quartz, $R$ - rutile); $B, C$-leucoxene grains with anatase inclusions: Rut - rutile, Ana - anatase, Psr - pseudorutile, Qrt quartz. Mineral phases determined by EBSD.

Iron in LC grains is concentrated inside aggregates and associated with pseudorutile relics with clear boundaries. Smaller sections of pseudorutile - residues of the primary mineral - are observed along the perimeter of relics. The volume fraction of quartz and aluminosilicate phases is from 18 to $38 \%$; average value of $28 \%$.
Thus, LC grains are a polymineral aggregate, the sizes of individual phases from a few micrometers to 100 micrometers. Quartz cannot be reliably separated by physical methods.

\subsection{Nanostructured titanium dioxide}

The synthesized sample, hereinafter NT, (Fig. 2) is a mixture of two phases: quartz and hydrated sodium titanate $\left(\mathrm{Na}_{\mathrm{x}} \mathrm{H}_{2-}\right.$ ${ }_{x} \mathrm{Ti}_{3} \mathrm{O}_{7}$ ). Chemical composition (wt.\%): $\mathrm{TiO}_{2}-74.68, \mathrm{SiO}_{2}$ - 12.64, $\mathrm{Fe}_{2} \mathrm{O}_{3}-5.44, \mathrm{Al}_{2} \mathrm{O}_{3}-4.71, \mathrm{Na}_{2} \mathrm{O}-0.14, \mathrm{~K}_{2} \mathrm{O}-0.93$, $\mathrm{MnO}-0.64, \mathrm{CaO}-0.12, \mathrm{MgO}-0.25, \mathrm{P}_{2} \mathrm{O}_{5}-0.09, \mathrm{ZrO}_{2}-0.08$, $\mathrm{NbO}-0.14$.

The formation of titanium dioxide nanotubes proceeds in several stages: a gradual dissolution of raw is accompanied by epitaxial growth of layered sodium titanate nanosheets $\rightarrow$ nanolayer delamination $\rightarrow$ twisting of nanosheets into tubes $\rightarrow$ nanotube growth along $\mathrm{X}$ axis $\rightarrow$ exchange of sodium ions by protons during washing and separation of nanotubes from each other. When treated with alkali, the crystal lattice of the initial rutile turns into an amorphous product; after treatment with distilled water and a solution of hydrochloric acid, titanium dioxide nanotubes are formed [20]. According to [13], nanotubes consist of titanate layers, the composition of which depends on the synthesis conditions (temperature, processing time, ratio of liquid and solid phases). Tubular twisting of atomic layers is accompanied by a noticeable expansion of the shape of the peaks. Fig. $2 \mathrm{~A}$ shows indices of planes corresponding to the peaks of the diffraction pattern. The reflection characteristic of titanium dioxide nanotubes in the region $2 \theta=10^{\circ}$ can be attributed to $\mathrm{H}_{2} \mathrm{Ti}_{3} \mathrm{O}_{7}$ or $\mathrm{Na}_{\mathrm{x}} \mathrm{H}_{2-}$ ${ }_{x} \mathrm{Ti}_{3} \mathrm{O}_{7}$ crystals [21]. Reflexes (200) with an interlayer distance $0.96 \mathrm{~nm}$ correspond to the distance between two adjacent $\mathrm{TiO}_{6}$ octahedra that form the walls of the nanotubes.

Fig. 2 shows an electron microscopic image of the synthesized $\mathrm{TiO}_{2}$ nanotubes. The channels inside the obtained nanotubes are clearly visible. The resolution of a scanning electron microscope allows estimating their outer diameter (70-100 $\mathrm{nm})$.

Nanostructural rearrangement results in increasing specific surface and changing band gap. Measurements by low temperature nitrogen adsorption (BET) are given in Table 1.
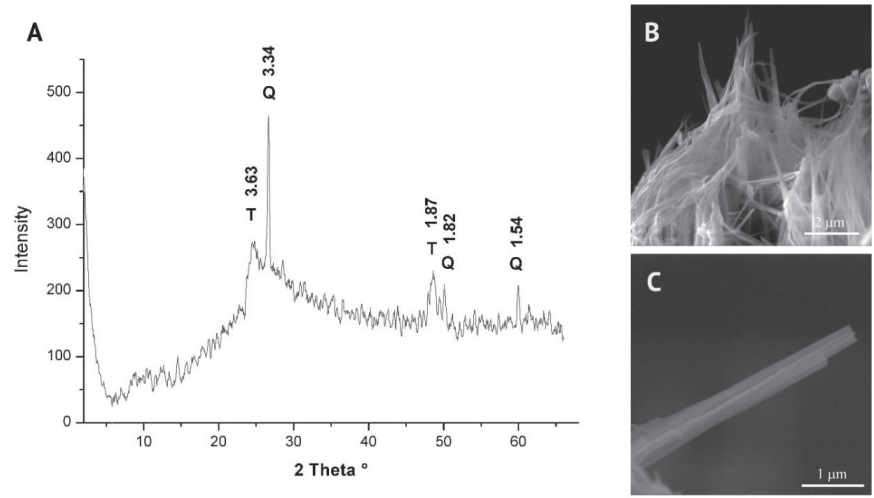

2. ábra $A$ - NT diffrakciós mintázat (Q-kvarc, T-nátrium-titanát); B, C-nanocsövek SEM képei

Fig. 2 A - NT diffraction pattern ( $Q$ - quartz, $T$ - sodium titanate); B, C-SEM images of nanotubes 


\begin{tabular}{lcc} 
Sample & Band gap (eV) & $\begin{array}{c}\text { Specific surface area, } \\
\text { average values }\left(\mathbf{m}^{2} / \mathbf{g}\right)\end{array}$ \\
\hline Anatase & 3.1 & 80 \\
\hline LC & 2.8 & 13 \\
\hline NT & 2.4 & 230 \\
1. táblázat & Sávrés és fajlagos felïlet \\
Table 1 & Band gap and specific surface area
\end{tabular}

The band gap was calculated by reflection spectra in the visible region based on the relationship of the adsorption coefficient $\alpha$ with the absorbed photon energy $h v$ [13]:

$\alpha=\frac{B_{i}\left(h v-\Delta E_{g}\right)^{2}}{h v}$,

where $B_{i}$ - adsorption constant for indirect i-transitions. Structural rearrangement at the nanoscale level - the formation of titanium dioxide nanotubes - results in decreasing band gap: anatase $-3.1, \mathrm{LC}-2.8, \mathrm{NT}-2.4 \mathrm{eV}$.

The change in physical and chemical properties allows considering the obtained nanostructured samples as promising photocatalysts and using them in water treatment systems.

\subsection{Study of photocatalytic properties}

The photocatalytic activity of the samples was studied by a trichlorophenol decomposition reaction test. Commercially available titanium dioxide powders Aeroxide Degussa P25 and Anatase (Aldrich), widely used as an active catalyst in water treatment systems, were used as composites. According to the manufacturer, P25 is a weakly aggregated powder, the surface area is $50 \mathrm{~m}^{2} / \mathrm{g}$, the phase composition $-25 \%$ rutile and $75 \%$. Anatase characteristics are given in Table 1.

The kinetics of the heterogeneous photooxidation reaction in liquid media in the presence of a catalyst is described by the Langmuir - Hinshelwood model [22]. In this model, the reaction rate $r$ is presented as a function of the degree of adsorbate coverage of active surface adsorption centers, which is assumed to be equal to the equilibrium adsorption $\theta$ associated with the concentration of adsorbate $\mathrm{C}$ through the equation of the Langmuir adsorption isotherm Eq. (1). The expression for the reaction rate should also contain other parameters, the consideration of which is possible only when constructing an adsorption model and adopting some simplifications. In particular, the size of the catalyst and the rate of transfer of active oxygen can be neglected. However, in this case as well, the process remains rather complicated for modeling, since the adsorption of trichlorophenol and decomposition products proceeds in parallel. Nevertheless, a fairly simple equation can be used if we consider only the process of photocatalytic decomposition of trichlorophenol (neglecting post-absorption). If we assume that the reaction rate between the adsorbate and the active Bronsted and Lewis surface centers $\left(\mathrm{h}^{+}\right.$and $\left.\mathrm{e}^{-}\right)$can be represented as $\mathrm{k} \theta$, and the recombination rate of electron-hole pairs $\mathrm{h}^{+} / \mathrm{e}^{-}(\mathrm{kr})$ is quite high $(\mathrm{kr}>>\mathrm{k} \theta)$, then

$r=-\frac{d C}{d t}=\frac{I \Phi}{k_{r}} k \theta=\frac{I \Phi}{k_{r}} k \frac{n K C}{1+K C}=k_{a p p} \frac{C}{1+K C}$

In the above equation, $\mathrm{I}$ - intensity of the incident radiation, $\Phi$ - degree of coverage of the surface of the sample by adsorbate, $\mathrm{n}$ - surface concentration of active centers, $\mathrm{K}$ - equilibrium adsorption coefficient. If the concentration of adsorbate $\mathrm{C}$ is small, then Eq. (2) can be represented as:

$r=k_{\text {app }} C$

In the integrated form, the last two equations, respectively

$\ln \left(\frac{C_{0}}{C}\right)+K\left(C_{0}-C\right)=k_{a p p} t$

and

$\ln \left(\frac{C_{0}}{C}\right)=k_{\text {app }} t$

In this case, for the decomposition reaction of trichlorophenol, taking into account Eq. (4), the time dependence is linear, and the slope gives the constant $\mathrm{k}_{\text {app }}$. Graphs of time dependence for the studied samples are presented in Fig. 3.
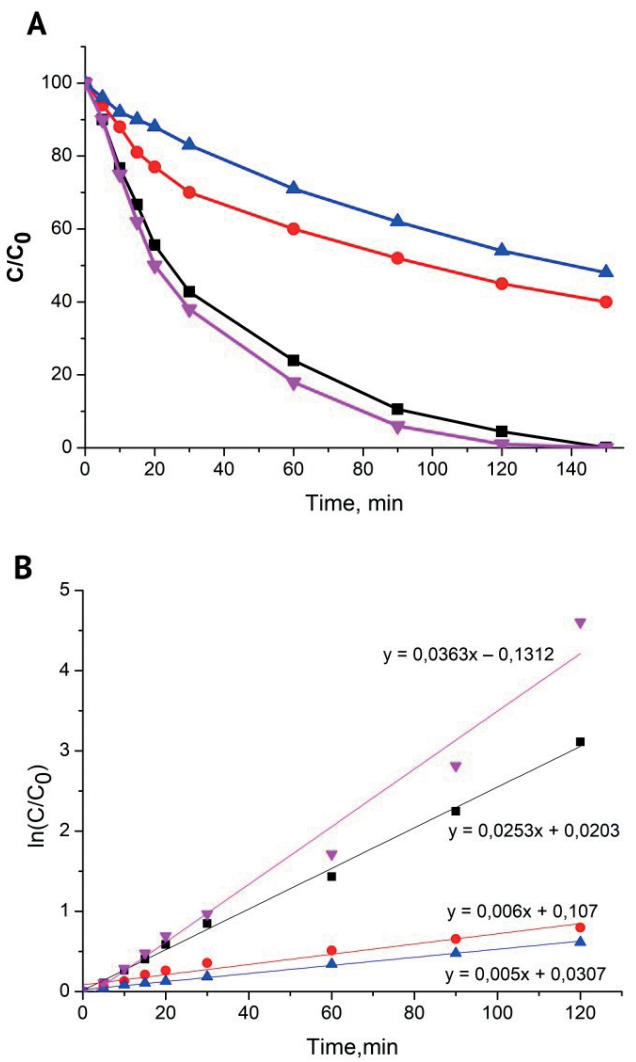

3. ábra A-Triklór-fenol lebomlási görbék vizes közegben; $B$ - a reakcióállandók

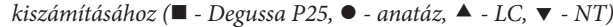

Fig. 3 A-Trichlorophenol degradation curves in an aqueous medium; $B$ - for calculation of reaction constants $(\boldsymbol{\square}$ - Degussa P25, $\bullet$ - anatase, $\boldsymbol{\Delta}-L C, \boldsymbol{\nabla}-N T)$

Linear approximation is applicableonlyin a certain timeinterval. This can be explained by the fact that post-absorption processes, i.e. interaction of the surface of the samples with intermediate products of the decomposition reaction of trichlorophenol were not taken into account. When using the Langmuir-Hinshelwood model, it is assumed that the rate of adsorption on the surface significantly exceeds the rate of the reaction proceeding at active surface centers, i.e. the liquid phase and the surface of the sample are constantly in a state of adsorption equilibrium. Although the adsorption and decomposition reactions on the surface proceed 
simultaneously, most likely, they do not determine the reaction rate. In the initial period of time $(0-10 \mathrm{~min})$, trichlorophenol is adsorbed on the surface of the sample and the reaction rate increases. Upon reaching complete coverage of the surface with the adsorbate, the reaction rate is maximum and does not change further. At this point, the decomposition reaction of trichlorophenol will be of zero order.

Based on the obtained data, the values of the reaction constants were calculated (Fig. 3 B): 0.005 for LC, 0.006 for anatase, 0.025 for Degussa P25, 0.036 for NT.

\section{Conclusions}

We have synthesized titanium dioxide nanotubes by the hydrothermal method. Affordable natural raw material - a gravity concentrate of titanium ore from the Pizhemskoe deposit - has been used as an initial material. The synthesized titanium dioxide nanotubes have an external diameter of 70$100 \mathrm{~nm}$. The synthesized material $-\mathrm{TiO}_{2}$ nanotubes have a developed surface, which gives it good sorption qualities.

We have studied dependence of the kinetics of photoinduced decomposition of trichlorophenol in aqueous solutions in the presence of various types of catalysts based on titanium dioxide: commercially available Degussa P25 and anatase (Aldrich), leucoxene concentrate (Pizhemskoe deposit), titanium dioxide nanotubes. The reaction constants of photoinduced decomposition of trichlorophenol are calculated. We have shown that titanium dioxide nanotubes are not inferior in characteristics to commercial analogues currently used as the basis for catalysts.

\section{Acknowledgements}

The authors are thankful to Geonauka Center for Collective Use, where we conducted our studies. The reported study was funded by RFBR and NSFC according to the research project RFBR № 20-55-53019 and NSFC № 42011530085, 41672039.

The studies were supported by the program "Main directions of integrated assessment and efficient use of georesources of Timan-Northern Ural-Barents Sea Region" GR AAAA-A17-117121270037-4.

\section{References}

[1] T.N., Shchemelinina - A. L., Gömze - O. B., Kotova - J.E.F.M., Ibrahim - D. A., Shushkov - M., Harja - G. V., Ignatiev - E. M., Anchugova (2019): Clay- and zeolite-based biogeosorbents: modelling and properties Építőanyag-JSBCM, Vol. 71, No.4, pp.131-137. p. https://doi.org/10.14382/epitoanyag-jsbcm.2019.23

[2] T., Shchemelinina - O., Kotova - M., Harja - E., Anchugova (2019): Biogeosorbents for solving ecological problems // IOP Conf. Series: Materials Science and Engineering Vol. 613, 012042 https://doi.org/10.1088/1757-899X/613/1/012042

[3] E., Kurovics - O. B., Kotova - A. L., Gömze - D. A., Shushkov - G. V., Ignatiev - P. A., Sitnikov - Y. I., Ryabkov - I. N.,Vaseneva - L. N., Gömze (2019): Preparation of particle-reinforced mullite composite ceramic materials using kaolin and IG-017 bio-origin additives Épitöanyag-JSBCM, Vol. 71, No.4, pp.114-119. https://doi.org/10.14382/epitoanyag-jsbcm.2019.20

[4] K. D., Kumar - G. P., Kumar - K. S., Reddy (2015): Rapid Microwave Synthesis of Reduced Graphene Oxide-supported TiO Nanostructures as High Performance Photocatalyst. Materials Today. No. 2, pp. 3736-3742.

[5] W., Zhang - C. R., Ou - Z.G., Yuan (2017): Precipitation and growth behaviour of metatitanic acid particles from titanium sulfate solution. Powder Technology, No.315, pp. 31-36.

[6] O. B., Kotova - I. L., Shabalin - D. A., Shushkov - A. V., Ponaryadov (2015): Sorbents based on mineral and industrial materials for radioactive wastes immobilization. Vestnik of Insitute of Geology, Vol. 2, pp. 32-34.
[7] J. E. F. M., Ibrahim - A. L., Gömze - O. B., Kotova - T. N., Shchemelinina D. A., Shushkov - G.V., Ignatiev - E. M., Anchugova (2019): The influence of composition, microstructure and firing temperature on the density, porosity, and shrinkage of new zeolite-alumina composite material. Épitöanyag-JSBCM, Vol. 71, No.4, pp.120-124. https://doi.org/10.14382/epitoanyag-jsbcm.2019.21

[8] D. P., Penaloza Jr. (2019): Enhanced mechanical, thermal and barrier properties of clay-based polymer nanocomposite systems. ÉpitöanyagJSBCM Vol. 71 No. 3 pp. 74-79. https://doi.org/10.14382/epitoanyag-jsbcm.2019.13

[9] O. B., Kotova - D. A., Shushkov - A. L., Gömze - E., Kurovics - G. V., Ignatiev - P. A., Sitnikov - Y. I., Ryabkov - I. N., Vaseneva (2019): Composite materials based on zeolite-montmorillonite rocks and aluminosilicate wastes. Építöanyag-JSBCM, Vol. 71, No.4, pp. 125-130. https://doi.org/10.14382/epitoanyag-jsbcm.2019.22

[10] F., Hu - Y., Wen - K. C., Chan - T. M., Yue - Y. Z., Zhou - S. L., Zhu - X. J., Yang (2015): Synthesis of self-detached nanoporous titanium-based metal oxide. Journal of Solid State Chemistry Vol. 229, Pages 78-86 https://doi.org/10.1016/j.jssc.2015.05.021

[11] S., IIssar - A. K., Mahapatro (2019): Hydrothermally grown rutile titanium dioxide nanostructures with various morphologies. Materials Science in Semiconductor Processing, Vol. 104, 104676. https://doi.org/10.1016/j.mssp.2019.104676

[12] O. B., Kotova - M.,Harja - L. N., Kotov - A. V., Ponaryadov (2018): Titanium minerals as prototypes of functional materials with pronounced electromagnetic properties. Vestnik IG Komi SC UB RAS. No. 4. C. 34-39.

[13] L. H., Huang - C., Sun - Y. L., Liu (2007) Pt/N-codoped $\mathrm{TiO}_{2}$ nanotubes and its photocatalytic activity under visible light. Applied Surface Science, Vol. 253, pp. 7029-7035.

[14] H.-L., Kuo - C.-Y., Kuo - C.-H., Liu - J.-H., Chao - C.-H., Lin (2007): A highly active bi-crystalline photocatalyst consisting of $\mathrm{TiO}_{2}(\mathrm{~B})$ nanotube and anatase particle for producing $\mathrm{H} 2$ gas from neat ethanol. Catalysis Letters, Vol. 113. P. 7-12.

[15] T. W. P., Seadira - G., Sadanandam - T., Ntho - C. M., Masuku - M. S., Scurrel (2018): Preparation and characterization of metals supported on nanostructured $\mathrm{TiO}_{2}$ hollow spheres for production of hydrogen via photocatalytic reforming of glycerol. Applied Catalysis B: Environmental, Vol.222, pp.133-145

[16] N., Wang - X., Li - Y., Wang - X., Quan - G., Chen (2009): Evaluation of bias potential enhanced photocatalytic degradation of 4-chlorophenol with $\mathrm{TiO}_{2}$ nanotube fabricated by anodic oxidation method. Chemical Engineering Journal, Vol. 146, pp. 30-35.

[17] Duduman C. N., - Gómez de Salazar y Caso de Los CobosJ. Harja M., Barrena Pérez M. I., Gómez de Castro C., Lutic D., Kotova O., Cretescu I. (2018): Preparation and characterisation of nanocomposite materials based on $\mathrm{TiO}_{2}-\mathrm{Ag}$ for environmental applications. Environmental Engineering and Management Journal. Vol.17, No. 4, pp. 2813-2821.

[18] O., Kotova - E., Ozhogina - A., Ponaryadov - I., Golubeva (2016): Titanium minerals for new materials. IOP Conf. Series: Materials Science and Engineering, 012025 https://doi.org/10.1088/1757-899X/123/1/012025

[19] A. V., Ponaryadov (2017) Mineralogical and technological features of ilmenite-leucoxene ores of Pizhemskoe deposit, Middle Timan. Vestnik of the Institute of Geology, Komi SC UB RAS. No. 1. pp. 29-36. https://doi.org/10.19110/2221-1381-2017-1-29-36 (in Russian)

[20] O. B., Kotova - A. V., Ponaryadov - L. A., Gömze (2016): Hydrothermal synthesis of $\mathrm{TiO}_{2}$ nanotubes from concentrate of titanium ore Pizhemskoe deposit (Russia). Vestnik IG Komi SC UB RAS, No.1, pp. 34-36.

[21] Th., Streethawong - Y., Suzuki - S., Yoshikawa (2005): Synthesis, characterization, and photocatalytic activity for hydrogen evolution of nanocrystalline mesoporous titania prepared by surfactant-assisted templating sol-gel process. Journal of Solid State Chemistry, Vol. 178, pp. 329-338.

[22] Alaoui, O. Tahiri - Nguyen, Q. T. - Mbareck, C. - Rhlalou, T. (2009): Elaboration and study of poly (vinylidene fluoride)-anatase $\mathrm{TiO}_{2}$ composite membranes in photocatalytic degradation of dyes, Applied Catalysis A General Vol. 358, pp. 13-20.

\section{$\underline{\text { Ref.: }}$}

Ponaryadov, Aleksei V . - Kotova, Olga B. - Tihtih, Mohammed Sun, Shiyong: Natural titanium dioxide nanotubes Építőanyag - Journal of Silicate Based and Composite Materials, Vol. 72, No. 5 (2020), 152-155. p. https://doi.org/10.14382/epitoanyag-jsbcm.2020.25 